\title{
Bilingual parsing strategies in Basque and Spanish
}

\author{
Michael J. Leeser \\ Florida State University \\ Raquel Prieta \\ Oakland University
}

\begin{abstract}
Over the last several years, one area of sentence processing research that has received considerable attention is how native speakers resolve structural ambiguities while reading, as in Someone shot the servant of the actress who was on the balcony (e.g., Cuetos \& Mitchell 1988). Cross-linguistic research on this kind of ambiguous relative clause $(R C)$ attachment has revealed that speakers of some languages prefer to attach the $R C$ who was on the balcony to the first noun phrase (the servant), whereas speakers of other languages prefer attachment to the second noun phrase (the actress). From the perspective of bilingual sentence processing, research on $R C$ attachment can provide insight into a number of important issues related to language transfer, language attrition, and processing efficiency. The present study, therefore, seeks to build upon some of these lines of research by examining the on-line parsing strategies among native speakers of Basque $(\mathrm{N}=17)$ on two self-paced reading tasks in Basque and Spanish. Our purpose was to investigate which parsing routines these bilinguals utilized for each language in order to determine whether they maintained separate strategies or adopted one strategy for both languages. Analyses of reading times at critical regions in experimental sentences suggest that this group of bilinguals employed a single parsing strategy in Basque and Spanish. The findings are discussed within recent proposals of monolingual and bilingual sentence processing.
\end{abstract}

Keywords: relative clauses, attachment preferences, parsing strategies, sentence processing, Basque-Spanish bilinguals, structural ambiguity, self-paced reading.

\section{Bilingual parsing strategies in Basque and Spanish}

Sentence processing in native speakers and bilinguals has received considerable attention in recent years, particularly with regard to (a) how native speakers resolve structural ambiguities while reading (e.g, Fodor 2002; Frazier \& Clifton 1996; Gibson \& Pearlmutter 1998; Hemforth, Konieczny \& Scheepers 2000) and (b) whether parsing routines in one language affect the parsing routines of another language 
among bilinguals (e.g., Dussias 2003; Fernández 2002). One structure commonly used to investigate these issues involves relative clause attachment to complex noun phrases, as in the following example from Cuetos and Mitchell (1988):

(1) Someone shot the servant of the actress who was on the balcony.

Sentences such as (1) have been of interest within sentence processing research because there is more than one way to interpret the sentence. The relative clause (RC) who was on the balcony can potentially modify the first noun phrase (NP1: the servant), or it could modify the second noun phrase (NP2: the actress). One of the earliest proposed principles of sentence parsing to address resolving these kinds of ambiguities is a universal parsing strategy known as late closure (Frazier 1978). According to this principle, new material should be attached to the phrase currently being processed in order to reduce the burden on working memory resources during parsing. In the case of the example in (1), the relative clause who was on the balcony should attach to the most recent NP the actress, resulting in what has been referred to as low attachment. Although late closure or low attachment has been observed in English (e.g.,Frazier 1987; Frazier \& Rayner 1982), challenges to the universality of late closure have come from Cuetos and Mitchell (1988), whose data suggest that native Spanish speakers prefer attaching the RC to the first noun phrase (i.e., the servant), also known as high attachment. Over the last several years, research on the processing of ambiguous RCs has revealed a preference for low attachment among speakers of Arabic (Abdelghany \& Fodor 1999), Brazilian Portuguese (Miyamoto 1998), English (e.g., Carreiras \& Clifton 1999), Norwegian, Swedish and Romanian (Ehrlich, Fernández, Fodero, Stenshowel \& Vinereanu 1999). A preference for high attachment has been found for native speakers of Dutch (Brysbaert \& Mitchell 1996), French (e.g., Frenck-Mestre \& Pynte 2001), German (Hemforth, Konieczny, Scheepers \& Strube 1998), Greek (Papdopoulou \& Clahsen 2003), and Spanish (Carreiras \& Clifton 1999; Dussias 2003). The fact that RC attachment ambiguities occur in many different languages has made it an ideal structure to test various theoretical proposals concerning language processing and parsing. Furthermore, from the perspective of bilingual sentence processing, research on $\mathrm{RC}$ attachment can provide insight into a number of important issues related to language transfer, language attrition, and processing efficiency. The present study seeks to build upon some of these lines of research by examining the on-line parsing strategies among native speakers of Basque in both Basque and Spanish. Our purpose is to investigate which parsing routines these bilinguals utilize for each language in order to determine whether they maintain separate strategies or adopt one strategy for both languages.

\section{Background}

\subsection{Relative clause attachment preferences in native speakers}

Because RC attachment ambiguities, such as (1), are resolved differently across various languages, a number of theoretical proposals have been developed to explain cross-linguistic differences in parsing strategies. These proposals include Construal (Frazier \& Clifton 1996), Attachment-Binding (Hemforth et al. 1998), Recency/ 
Predicate Proximity (Gibson \& Pearlmutter 1998; Gibson, Pearlmutter, CansecoGonzalez \& Hickok 1996), Tuning (Mitchell \& Cuetos 1991), and Implicit Prosody Hypothesis (Fodor 2002). In this section, we limit ourselves to providing a brief overview of Tuning, Attachment-Binding, and Recency/Predicate Proximity because of their relevance to the present study.

Mitchell and Cuetos (1991) proposed the tuning hypothesis (see also Cuetos, Mitchell \& Corley 1996), which is an exposure-based proposal in which the parser tabulates resolutions of ambiguities when encountered in the input. According to this hypothesis, initial parsing decisions are not determined by linguistic principles, «but by the experience the individual reader or listener may have had on previous encounters with ambiguities of the same kind. Put simply, the proposal is that, faced with an ambiguity, the reader/listener will initially opt for the resolution that has turned out to be appropriate most frequently in the past» (Cuetos et al. 1996: 154155). In other words, parsing decisions are governed by statistical properties of a particular ambiguity of a given language. Upon encountering and resolving these ambiguities, the parser adjusts or tunes itself toward that parsing routine. The more frequently a given routine has resulted in successful interpretations in the past, the more likely that routine will be used in the future to resolve similar ambiguities. Predictions for RC attachment are made based on corpus analyses of ambiguity resolutions of structures containing a complex NP and RC. For example, Mitchell et al. (1992) found that corpus data revealed that most RC attachment ambiguities in English are resolved via low attachment, whereas corpus data from Spanish show that these same ambiguities are consistently resolved via high attachment.

The attachment-binding hypothesis (Hemforth et al. 1998) proposes that RC attachment is resolved via two competing processes: anaphoric and syntactic processes. On the one hand, anaphoric processes attempt to bind the relative pronoun heading a RC to the most salient antecedent, which is generally the first NP in complex NP constructions, thereby favoring high attachment. On the other hand, syntactic processes favor attachment to the most recent phrase (NP2), resulting in low attachment. The strength of anaphoric processes depends on whether a given language requires a relative pronoun to introduce a RC. That is, in languages that require relative pronouns to head a RC, such as German and Spanish, attachment preferences will be sensitive to general constraints on pronouns, specifically to an anaphoric binding constraint, according to which pronouns have to be attached to salient discourse nouns. The salience of the nouns is determined by focus and thematic alignment, usually rendering NP1 more salient than NP2, resulting in high attachment. Because relative pronouns (e.g., who, which) can be omitted or replaced by a complementizer (that) in English, anaphoric processes play a reduced role, allowing for syntactic processes to predominate, thereby resulting in low attachment.

Gibson and Pearlmutter's (1998) multiple-constraint model proposes two interacting factors that determine RC attachment, Recency and Predicate Proximity. The attachment decision depends on the relative strength of these two competing factors. The first factor, Recency, is similar to late closure in that the parser prefers to attach incoming lexical items to most recently built structure, resulting in low attachment. Because this factor follows from general principles of working memory, the strength of Recency does not vary cross-linguistically. The second factor, 
Predicate Proximity, favors attachment as close as possible to the head of a predicate phrase (verb phrase), therefore resulting in high attachment. Unlike Recency, the strength of Predicate Proximity varies from language to language and is determined by the structural distance between a verb and its arguments (e.g., subject and object). In other words, because language like Spanish and German allow greater distance between a predicate and its arguments, such as allowing adjuncts between a verb and its object, there is a stronger activation of Predicate Proximity, which results in high attachment. However, languages like English, Norwegian and Swedish do not allow adverbial phrases between the verb and an object, thereby weakening any influence of predicate proximity and allowing a greater influence of Recency.

The three proposals outlined in this section can explain the consistent findings that Spanish monolinguals demonstrate a preference for high attachment, whereas English monolinguals generally prefer low attachment: corpus analyses in each language of ambiguity resolutions (Tuning Hypothesis), stronger anaphoric processes in Spanish due to obligatory relative pronouns but stronger syntactic processes in English (Attachment-Binding), and stronger activation of Predicate Proximity in Spanish due to its more flexible word order compared with English (Predicate Proximity/Recency). Because corpora for Basque are limited, it is difficult to examine the frequency distribution of $\mathrm{RC}$ attachments to test the Tuning Hypothesis; however, we will consider this hypothesis when reviewing previous data for bilinguals and data from the present study. That said, Basque does have morphosyntactic properties that are advantageous for testing AttachmentBinding and Predicate Proximity/Recency accounts of RC attachment preferences. In the next section, therefore, after providing a brief overview of the syntactic structure of RCs in Basque, we turn to the predictions of these models for native Basque speakers.

\subsection{Basque sentence structure and relative clauses}

Basque is an SOV language that allows relatively free word order and has a rich system of inflectional morphology. It is a head-final language in which RCs are headed by complementizers or what are called derivative morphemes. RCs in Basque lack an overt relative pronoun, and thus, the $\mathrm{RC}$ is going to be marked by the $(e)-n$ attached to the auxiliary verb, as in (2):

(2) Izozkia jaten duen mutilaren lagunarekin elkartuko naiz. Ice cream eat aux $_{\text {REL }}$ boy $_{\text {GEN }}$ friend-with meet-will aux 'I will meet with the friend of the boy who was eating an ice-cream'

In (2), the RC is marked by the complementizer -en in the auxiliary verb duen. According to attachment-binding, we would therefore expect to find a low attachment preference in Basque sentences. At the same time, however, because Basque has relatively free word order, Recency/Predicate Proximity would predict high attachment due to a stronger role for predicate proximity. These two frameworks, then, make opposing claims regarding RC attachment in Basque. Yet, to our knowledge, only one off-line, unpublished study has examined RC attachment for Basque speakers. 
Gutiérrez, Carreiras \& Laka (2004) administered questionnaires in Basque and Spanish to different groups of Basque-Spanish bilinguals (early L1 Basque bilinguals, early L1 Spanish bilinguals, L1 Basque and Spanish bilinguals). Each questionnaire contained ambiguous RCs, as in (3) and (4):

(3) Lanari buruz asko hitz egiten duen mutilaren lagunarekin elkartuko naiz Work $_{\text {DAT }}$ about a lot speak Aux REL $_{\text {boy }}$ friend-with meet FUT $_{\text {Aux }}$

(4) $\mathrm{Me}$ reuniré con el amigo del chico que habla mucho sobre el trabajo. I will meet with the friend GEN boy that speaks a lot about the work 'I will meet with the friend of the boy who speaks a lot about work'

The sentences were followed by questions to determine how the participants disambiguated the sentence (e.g., Who speaks a lot about work?). The results from the Basque questionnaire revealed a low attachment preference for Basque among all the bilingual groups, thereby supporting the Attachment-Binding hypothesis, at least regarding Basque speakers' final interpretation of sentences. For the Spanish sentences, unlike the findings of other studies that have reported a high attachment preference for monolingual Spanish-speakers, two of the Basque-Spanish bilingual groups (L1 Basque and simultaneous Basque/Spanish) demonstrated a preference for low attachment in Spanish. No clear attachment preference in Spanish was found for L1 Spanish bilinguals or Spanish monolinguals living in the Basque Country.

The data obtained from the questionnaires suggest some of the bilinguals adopted one parsing strategy for both languages. Yet, off-line measures, such as the questionnaires used in Gutiérrez et al., cannot inform us about the bilinguals' moment by moment processing or their initial parsing strategy. For this reason, the present study examines L1 Basque speakers' on-line parsing in self-paced reading tasks in Basque and Spanish. Because Spanish is a co-official language along with Basque in the Basque Autonomous Community (BAC), and is the majority language in Spain, L1 Basque speakers from the BAC also grow up speaking and receiving instruction in Spanish. For this reason, before explaining the current study, we will look at some of the studies that have used on-line methods to examine RC attachment for Spanish bilinguals.

\subsection{Relative clause attachment in Spanish bilinguals}

Due to the cross-linguistic differences among native speakers of different languages, a primary focus on bilinguals' processing of complex NP-RC constructions has focused on whether second language (L2) learners can adopt a new parsing routine in the second language, particularly when that routine differs from the native language. Although no consensus currently exists concerning whether L2 learners can adopt native-like processing routines of monolinguals in the target language (see, e.g., discussion in Clahsen \& Felser 2006) of particular interest for the present study is that, in some cases, bilinguals' parsing strategies for the two languages seem to converge onto one strategy. For example, Dussias (2003) and Dussias and Sagarra (2007) reported that some L1 Spanish L2 English bilinguals seemed to employ low attachment for both Spanish and English. In these studies, 
participants read sentences containing complex NPs followed by relative clauses, in which disambiguating information in the RC forced either a low attachment interpretation (5a) or a high attachment interpretation (5b), as in the following examples from the eye-tracking study reported in Dussias and Sagarra:

(5) a. El policía arrestó al hermano de la niñera que estaba «The police arrested the brother of the baby-sitter ${ }_{\mathrm{FEM}}$ who had been enferma desde hacia tiempo.

ill ${ }_{\mathrm{FEM}}$ for a while.»

b. El policía arrestó a la hermana del criado que estaba "The police arrested the sister of the servant ${ }_{\text {MASC }}$ who had been enferma desde hacia tiempo.

ill $_{\text {FEM }}$ for a while.»

Although monolingual Spanish speakers demonstrated faster reading times when the disambiguating segment forced high attachment (5b) than if it forced low attachment (5a), the opposite pattern was found for the L1 Spanish-L2 English bilinguals who lived in the United States and had extensive exposure to English-an average of 8 years in Dussias (2003) and 7.1 years in Dussias and Sagarra (2007). These bilinguals were faster for the segments forcing low attachment than those forcing high attachment. In other words, even though Spanish is a language in which monolinguals have consistently demonstrated a high attachment interpretation when ambiguous relative clauses follow a complex NP (Carrieras \& Clifton 1999; Cuetos \& Mitchell 1998), the Spanish-English bilinguals, who were native speakers of Spanish, favored low attachment instead. One of the reasons put forth for this finding is that these bilinguals were living in a predominantly English-speaking environment in the U.S. This immersion in a linguistic environment, in which low attachment is the predominant parsing routine when relative clauses follow complex genitive antecedents, may have altered the parsing processes of the L1.

The bilinguals in Dussias (2003) and Dussias and Sagarra (2007) began acquiring an English as an L2 during adolescence/early adulthood in their home country and were living and working in a predominantly monolingual environment in the U.S. Although this situation represents a reality for many bilinguals, particularly in the United States, the present study examines bilinguals in the Basque Country, in which many bilinguals acquire Basque and Spanish in childhood and have regular exposure to both languages. Therefore, the purpose of the present study is to examine the parsing strategies of Basque-Spanish bilinguals that grow up with two languages to investigate which parsing strategies they employ while reading temporarily ambiguous relative clause constructions in Basque and in Spanish in an on-line self-paced reading task.

\section{Method}

\subsection{Participants}

The participants of this study consisted of 17 Basque-Spanish early bilinguals and were recruited via snowball sampling. All participants were born in the Basque 
country, reported Basque as their first language (L1), and had lived in the Basque country all their lives. The average age of the participants was 30.3 years. Although some of the participants reported some basic knowledge of English, none of the participants were proficient English speakers, thereby reducing the potential of an L3 influence in the experiment.

In order to assess the linguistic profiles of the participants, they completed the Language Experience and Proficiency Questionnaire (LEAP-Q, Marian, Blumenfeld \& Kaushanskaya 2007), In this questionnaire, learners rate their capabilities (on a scale from 1-10) in various language skills, such as speaking, reading, listening, and so forth. Furthermore, participants provide information about the amount of time they use each of the languages they speak, as well as how much they identify with the culture of each language. Table 1 displays the mean selfratings for the participants for Basque and Spanish.

Table 1

Self-ratings for Basque and Spanish

\begin{tabular}{|l|c|r|r|r|}
\hline & \multicolumn{2}{|c|}{ Basque } & \multicolumn{2}{c|}{ Spanish } \\
\cline { 2 - 5 } & $\boldsymbol{M}$ & $\boldsymbol{S D}$ & $\boldsymbol{M}$ & \multicolumn{1}{c|}{$\boldsymbol{S D}$} \\
\hline Usage (\%) & 71.47 & 13.20 & 20.88 & 77.50 \\
Speaking & 9.76 & 0.56 & 8.65 & 1.17 \\
Listening & 9.76 & 0.56 & 8.59 & 1.17 \\
Reading & 9.76 & 0.56 & 8.35 & 1.22 \\
Cultural Identity & 7.77 & 1.53 & 3.54 & 1.80 \\
\hline
\end{tabular}

Note. All ratings (except usage) are on a scale from 1 (lowest) to 10 (highest).

The data in Table 1 reveal that these bilinguals rate their abilities quite high in both Basque and Spanish, although the ratings are consistently higher for Basque, $t s(16)>3.95, p s \leq .001$. They also report using Basque more than three times as much as they use Spanish on a daily basis. Furthermore, they identify more strongly with Basque culture than with Spanish culture.

\subsection{Materials}

Two self-paced reading tasks were developed, one in Basque and one in Spanish. Each task consisted of 64 sentences (16 target sentences and 48 fillers). To test for attachment preferences in Spanish, we used 16 sentence pairs, which were based on the materials used in Dussias and Sagarra (2007). Each sentence pair contained a complex NP, which consisted of one masculine singular noun and one feminine singular noun, followed by a relative clause. One version in each sentence pair disambiguated toward high attachment, whereas the other version disambiguated toward low attachment, as illustrated in $(6 a-b)$ : 
(6) a. El hombre gritó al hermano de la amiga que estaba The man shouted at the brother ${ }_{\mathrm{MASC}}$ of the friend $\mathrm{FEM}_{\mathrm{F}}$ who was sentado en el banco. seated $_{\text {MASC }}$ on the bench.

b. El hombre gritó a la hermana del amigo que estaba The man shouted at the sister $_{\mathrm{FEM}}$ of the friend ${ }_{\mathrm{MASC}}$ who was sentado en el banco. seated $_{\text {MASC }}$ on the bench.

In $6 a$, the relative clause que estaba sentado en el banco contains a masculine adjective sentado. In order to satisfy gender/number agreement for Spanish nouns and their modifiers, the masculine singular adjective sentado in the relative clause modifies the masculine singular noun hermano in the complex NP, thereby forcing high or non-local attachment. For the low or local attachment condition (6b), the gender of the nouns in the complex NP was switched. Therefore, the adjective sentado must refer to amigo, resulting in low or local attachment. The difference between the two versions of each pair, then, was the gender of the nouns in the complex NP. All 16 sentence pairs can be found in Appendix A.

For the Basque experiment, 16 sentences pairs were created; however, because Basque does not have grammatical gender agreement like Spanish, the sentences could not be disambiguated by morphological gender. Therefore, the disambiguating region of the Basque sentences contained information normally associated with males (7a) or females (7b).

(7) a. Iratxek soineko gorria daraman emakumearen nebari gutun bat Iratxe dress red wear REL $_{\text {woman }}$ GEN brother $_{\text {DAT }}$ letter one idatzi zion.

write (Aux)

'Iratxe wrote a letter to the brother of the woman who wore a red dress.'

b. Iratxek papertxori gorria daraman emakumearen nebari gutun bat Iratxe bow tie red wear ${ }_{\mathrm{REL}}$ woman $_{\mathrm{GEN}}$ brother $_{\mathrm{DAT}}$ letter one idatzi zion.

write (Aux)

'Iratxe wrote a letter to the brother of the woman, who wore a red bow tie.'

In $7 \mathrm{a}$, the relative clause soineko gorria daraman ('who wore a red dress') is more likely to be associated with emakumea ('woman') than neba ('brother'), which would force local (low) attachment. In contrast, in $4 \mathrm{~b}$ the relative clause papertxori gorria daraman ('who wore the red bow tie') is more likely to be associated with neba than with emakumea, thereby disambiguating toward non-local (high) attachment. The Basque sentences pairs can be found in Appendix B.

For both Spanish and Basque experiments, the 16 target sentences were intermixed among 48 fillers sentences and distributed across two different presentation lists. Half of the target sentences disambiguated toward high attachment, and the other half disambiguated toward low attachment. Each list contained only one version of a sentence within a sentence pair. Items within each list were pseudorandomized to ensure that the target sentences of the same type (high or low attachment) never 
appeared consecutively. Half of all sentences (target and filler) were followed by a yes/ no comprehension question to ensure that participants were reading the sentences for meaning (e.g., Was the brother on the bench?). Half of the comprehension yes/no questions required yes answers and half no.

\section{Procedure}

The presentation of all sentences and the tracking of participants' performance were conducted using SuperLab experiment building software from Cedrus. Each sentence trial began with a series of underscores that indicated the length of each segment in the sentence. Upon pressing a button, the first segment appeared. Subsequent button presses revealed the remaining segments. The presentation was noncumulative, such that each button press revealed the next segment as the previous segment disappeared. This noncumulative, segment by segment presentation allowed the computer to record the reading times of each segment in milliseconds and prevented participants from rereading previous segments. An asterisk marked the end of a sentence, which signaled to the participant that the next button press would reveal either a new sentence or a comprehension question.

Participants were tested individually in one session lasting approximately 30 to 45 minutes. They were provided with general information about the study and then completed a consent form and background questionnaire. Each participant was then assigned one of the experimental lists in one of the languages. They were instructed that they would read individual sentences in Basque or Spanish on the computer screen and that each sentence would be displayed one segment or phrase at a time. After reading the instructions and having the opportunity to ask questions, they completed 5 practice trials followed by the 64 sentences. Half of the participants completed the self-paced reading task in Basque first; the other half completed the Spanish task first. Upon completion of the first self-paced reading task, they were informed that they completed the first task. Whenever they ready, they began a computerized operation span task in Spanish, which served as a distracter task between the two main self-paced reading tasks. After completing the operation span, they could begin the self-paced reading task in the other language. The experiment lasted no longer than 45 minutes for any single participant.

\subsection{Data selection and analyses}

The sentences were divided into segments or regions, as in (8a-b) for Spanish and (9a-b) for Basque.

(8) a. El hombre gritó / al hermano de la amiga / que estaba sentado / en el banco. / b. El hombre gritó / a la hermana del amigo / que estaba sentado / en el banco. / 1 2

34

(9) a. Iratxek / soineko gorria daraman / emakumearen nebari / gutun bat idatzi zion. / b. Iratxek / papertxori gorria daraman / emakumearen nebari / gutun bat idatzi zion. / 1 2 3 
For the Spanish sentences, region 3 served as the critical region and is the location of the disambiguating adjective. Thus, if participants show a preference for low attachment, we expected longer reading times at this segment for sentences like 8 a due to the difficulty of attaching the disambiguating information to the first NP. Alternatively, if participants prefer high attachment, we would expect longer reading times at this region for sentences like $8 \mathrm{~b}$. Region 4 was also included in the analyses to account for spillover effects, in which processing time for a given region may «spill over» into the next region.

For the Basque sentences, the critical region was also region 3; however, because of Basque word order, this disambiguating region is actually the complex NP, which follows the relative clause. In this case, if participants prefer low or local attachment, we would expect faster reading times in region 3 for sentences like 9a. If they prefer high or non-local attachment, we would expect faster reading times in the same region for sentences like 9b. As with the Spanish sentences, we included region 4 in the analyses to account for spillover effects.

For each self-paced reading experiment, mean reading times for each participant were calculated separately for the two attachment conditions (local and non-local) at each region of interest. The mean reading times for high and low attachment sentences were submitted to paired-samples t-tests for each region, with an $\alpha$-level set at .05. For statistically significant findings, effect sizes for the high and low attachment comparison were calculated (Cohen's $d$ ), for which Cohen's $d>1.0$ is considered a large effect (Cohen 1988).

\section{Results}

An overview of participants' mean reading times for each sentence region for the Basque sentences is provided in table 2. In the first two regions, there is little difference in reading times between high and low attachment sentences. In fact, paired-samples t-tests at regions 1 and 2 revealed no significant differences between the two sentence types, $t s<1.7, p s>.10$. However, reading times were significantly slower for high attachment sentences at the target region (region 3), $t(15)=5.13$, $p<.001, d=2.38$. At the spillover region (region 4 ), the difference between high and low attachment sentences approached significance, $t(15)=2.08, p=.055$, $d=1.39$.

Table 2

Mean reading times (and standard deviations) by region for Basque sentences

\begin{tabular}{|c|c|c|c|c|}
\hline Condition & Region 1 & Region 2 & Region 3 & Region 4 \\
\hline High Attachment & $\begin{array}{c}963 \\
(163)\end{array}$ & $\begin{array}{c}1411 \\
(178)\end{array}$ & $\begin{array}{c}2002 \\
(436)\end{array}$ & $\begin{array}{c}1061 \\
(194)\end{array}$ \\
\hline \multirow{2}{*}{ Low Attachment } & 996 & 1338 & 1270 & 842 \\
& $(206)$ & $(198)$ & $(180)$ & $(132)$ \\
\hline
\end{tabular}


Table 3 displays the means and standard deviations by region for the Spanish sentences. Similar to the patterns for Basque, the reading times at the target and spillover regions (regions 3 and 4, respectively) are consistently slower for high attachment sentences. Paired samples t-tests at regions 1 and 2 revealed no significant differences between the two sentence types, $t s<1.30$, $p s>.25$. However, reading times were significantly slower for high attachment sentences at the target region (region 3), $t(15)=7.07, p<.001$, Cohen's $d=1.86$; and at the spillover region (region 4), $t(15)=3.94, p=.001$, Cohen's $d=0.98$.

\section{Table 3}

Mean reading times (and standard deviations) by region for Spanish sentences

\begin{tabular}{|c|c|c|c|c|}
\hline Condition & Region 1 & Region 2 & Region 3 & Region 4 \\
\hline High Attachment & $\begin{array}{c}\text { 859 } \\
(246)\end{array}$ & $\begin{array}{c}1263 \\
(312)\end{array}$ & $\begin{array}{c}1895 \\
(406)\end{array}$ & $\begin{array}{c}979 \\
(306)\end{array}$ \\
\hline \multirow{2}{*}{ Low Attachment } & 912 & 1306 & 1012 & 701 \\
& $(300)$ & $(333)$ & $(289)$ & $(219)$ \\
\hline
\end{tabular}

To summarize, reading times at critical regions in Basque and Spanish sentences were significantly slower for sentences that forced high attachment than for the same regions in sentences that forced low attachment. The findings suggest that this group of Basque-Spanish bilinguals demonstrates a preference for low attachment in both languages.

\section{Discussion and conclusions}

This study set out to examine the parsing strategies of temporarily ambiguous relative clauses among native speakers of Basque in both Basque and Spanish. We wanted to see whether they would maintain separate strategies for each language (e.g., low for Basque and high for Spanish) or whether they would utilize one strategy for both. The results of the self-paced reading tasks indicate that these bilinguals employed low attachment in Basque and Spanish.

The findings for the Basque sentences lend support to previous offline research that L1 Basque speakers prefer low attachment (Gutierrez et al. 2004). Regarding the specific accounts proposed for RC attachment ambiguity resolution, the Basque data are compatible with the Attachment-Binding hypothesis (Hemforth et al. 2004). This hypothesis predicts that because relative pronouns in Basque are omitted and replaced by a complementizer, anaphoric processes play a reduced role. Therefore, syntactic processes predominate, resulting in low attachment. In contrast, our findings for Basque do not support Recency/Predicate Proximity (Gibson et al. 1996), which predicts that, because of the relatively flexible word order in Basque, Predicate Proximity will be activated more strongly, resulting in high attachment.

Unlike previous research that has reported high attachment preferences for Spanish monolinguals, our results indicate that these Basque-Spanish bilinguals 
prefer low attachment in Spanish. These findings do not support either AttachmentBinding or Recency/Predicate Proximity, both of which predict high attachment among Spanish speakers. One possible explanation for this finding is that the participants, native Basque speakers, have not acquired native-like processing in Spanish. That is, similar to the findings of adult L2 learners, they may not be making full use of syntactic information in the same way that native speakers do when processing sentences, resulting in what has been referred to as «shallow processing» (see, e.g., Clahsen \& Felser 2006). Although the participants reported better knowledge and greater usage of Basque than Spanish, they began acquiring Spanish at the age of 3, were educated in both Basque and Spanish, and live in an area where Spanish is the majority language and co-official with Basque. Therefore, it is unlikely that these bilinguals have not yet acquired native-like processing in Spanish.

A more plausible explanation for the low attachment preferences for Spanish found in the present study may be attributed to the fact the participants are bilinguals and not Spanish monolinguals. In fact, the Spanish findings for the Basque-Spanish bilinguals in this study are consistent with the findings for the (L1 Spanish) Spanish-English bilinguals reported in Dussias (2003) and Dussias and Sagarra (2007). Similar to the studies investigating Spanish-English bilinguals, the participants in the present study reported greater exposure to a low attachment language. That is, the Basque-Spanish bilinguals reported that they used Basque about three times as much as Spanish in their daily lives. From the perspective of a frequency-based framework such as the Tuning hypothesis, it is possible that this greater exposure to a low attachment language affected their processing of sentences in Spanish. However, it is still unclear whether the explanation for the findings of a convergence of parsing strategies in these studies lies solely in greater exposure to a low attachment language. It has been hypothesized that late closure or low attachment is a more efficient strategy in terms of cognitive resources and working memory, given that new material can be immediately integrated into the most recent phrase. Due to this reduced cognitive cost, then, it is possible that with regular use of two or more languages, for which different parsing routines have been reported, the parser defaults to the more economical strategy (i.e., low attachment) for both languages when processing ambiguous RCs.

In frameworks such as Attachment-Binding and Recency/Predicate Proximity, temporarily ambiguous $\mathrm{RC}$ constructions are resolved depending on the strength of two competing factors - a factor based on memory limitations (e.g., late closure) and a factor related to the linguistic properties of a given language (predicate proximity, anaphoric processes). The strength of late closure does not vary cross-linguistically because the strength of this factor stems from general principles of working memory. In contrast, the strength of a factor like anaphoric processes or predicate proximity depends on the syntactic features of a particular language. For bilinguals (and multilinguals), it could be the case that the strength of late closure is greater than the overall strength of a language-specific factor when that factor is weak (or non-existent) in one or more of the languages. For example, because Basque and English do not require an overt relative pronoun to introduce a relative clause, the cumulative strength of anaphoric processes may be less than the strength of late closure in Basque-Spanish bilinguals and English-Spanish bilinguals. In this view, 
frequency of exposure to the low attachment language plays a role up to a certain point. After that, regardless of which language is used more, the parser simply adopts the more efficient strategy in terms of cognitive resources (i.e., late closure).

Because the participants in the present study reported greater usage of Basque, our findings do not allow us to determine whether the convergence of parsing strategies can be attributed to greater exposure/language dominance or to the adoption of a more cognitively efficient parsing strategy. In order to determine which of these possibilities can better explain bilinguals' using one parsing strategy for both languages, future research will have to examine bilinguals that receive greater exposure to a high attachment language, as in the case of Basque-Spanish bilinguals who are Spanish dominant.

While we wait for future studies to tease apart some of the issues mentioned here, the findings of our on-line study suggest that native speakers of Basque employ low attachment in temporarily ambiguous RC constructions in Basque, in line with the Attachment-Binding hypothesis. In addition, these speakers employ the same low attachment strategy when processing similar structures in Spanish.

\section{References}

Abdelghany, H. \& Fodor, J. D., 1999, «Low attachment of relative clauses in Arabic». Poster presented at AMLaP (Architectures and Mechanisms of Language Processing), Edinburgh, UK.

Brysbaert, M. \& Mitchell, D. C., 1996, «Modifier attachment in sentence parsing: Evidence from Dutch». Quarterly Journal of Experimental Psychology, 49A, 664-695.

Carreiras, M. \& Clifton, C., 1999, "Another Word on parsing Relative Clauses: Eye tracking evidence from Spanish and English». Memory and Cognition, 27 (5), 826-833.

Clahsen, H. \& Felser, C., 2006, «How native-like is non-native language processing?». Trends in Cognitive Sciences, 10, 564-570.

Cuetos, F. \& Mitchell, D., 1988, «Cross-linguistic differences in parsing: Restrictions on the use of the Late Closure Strategy in Spanish». Cognition, 30, 73-105.

—, — \& Corley, M. M. B., 1996, «Parsing in different languages». In M. Carreiras, J. E. García-Albea \& N. Sebastián-Gallés (eds.), Language processing in Spanish (pp. 145187). Mahwah, NJ: Erlbaum.

Dussias, P. E., 2003, «Syntactic ambiguity resolution in L2 learners: Some effects of Bilinguality on L1 and L2 processing strategies». SSLA, 25, 529-557.

— \& Sagarra, N., 2007, «The effect of exposure on syntactic parsing in Spanish-English bilinguals». Bilingualism language and cognition, 10(1), 101.

Ehrlich, K., Fernández, E. M., Fodor, J. D., Stenshoel, E. \& Vinereanu, M., 1999, «Low attachment of relative clauses: New data from Swedish, Norwegian, and Romanian». Poster presented at the 12th annual CUNY conference on human sentence processing, New York, 18-20 March.

Fernandez, E., 2002, Bilingual sentence processing: Relative clause attachment in English and Spanish. Philadelphia: John Benjamins Publishing Company.

Frazier, L., 1978, On comprehending sentences: Syntactic parsing strategies. Unpublished doctoral dissertation, University of Connecticut, Storrs, CT. 
Frazier, L., 1987, «Sentence processing: A tutorial review». In M. Coltheart (ed.), Attention and performance XIl. Hillsdale, NJ: Erlbaum.

- \& Rayner, K., 1982, "Making and correcting errors during sentence comprehen- sion: eye movements in the analysis of structurally ambiguous sentences». Cognitive Psychology, 14, 178-210.

— \& Clifton, C., Jr., 1996, Construal. Cambridge, MA: MIT Press.

Frenck-Mestre, C. \& Pynte, J., 1997, «Syntactic ambiguity resolution while reading in second and native languages». The Quarterly Journal of Experimental Psychology, 50, 119-148.

Fodor, J. D., 2002, «Psycholinguistics cannot escape prosody». Paper presented at Speech Prosody 2002, April 11-13, Aix-en- Provence, France.

Gibson, E. \& Pearlmutter, N., 1998, "A corpus-based analysis of psycholinguistic constraints on prepositional phrase attachment». In C. Clifton, Jr., L. Frazier \& K. Rayner (eds.), Perspectives in sentence processing (pp. 181-198). Hillsdale, NJ: Erlbaum.

Gibson, E., N. Pearlmutter, E. Canseco-Gonzalez \& G. Hickok, 1996, «Recency Preferences in the Human Sentence Processing Mechanism». Cognition, 59, 23-59.

Gutierrez, E., Carreiras, M. \& Laka, I., 2004, "Who was on the balcony?: Bilingual sentence processing: Relative Clause Attachment in Basque and Spanish. Póster seleccionado». 17th CUNY Annual Conference on Language Processing, University of Maryland, USA.

Hemforth, B., Konieczny, L., Scheepers, C. \& Strube, G., 1998, «Syntactic ambiguity resolution in German». Syntax and Semantics, 31, 293-309.

_, - , Seelig, H. \& Walter, M., 2000c, "Case matching and relative clause attachment in German». Journal of Psycholinguistic Research, 29, 81-88.

Mitchell, D. C. \& Cuetos, F., 1991, «The origins of parsing strategies». In C. Smith (ed.), Current issues in natural language processing. Austin: University of Texas, Centre for Cognitive Science.

—, Corley, M. M. B. \& Garnham, A., 1992, «Effects of context in human sentence parsing: Evidence against a discourse- based proposal mechanism». Journal of Experimental Psychology: Learning, Memory, \& Cognition, 18, 69-88.

Papadopoulou, D. \& Clahsen, H., 2003, "Parsing strategies in L1 and L2 sentence processing: A study of relative clause attachment in Greek». Studies in Second Language Acquisition, 24, 501-528.

\section{Appendix}

\subsection{Distracters in Spanish}

1. El doctor miraba a la enfermera mientras hablaba por teléfono.

2. El estudiante contestaba al profesor cuando le preguntaba en clase.

3. Los jugadores volvieron al estadio donde fueron derrotados hace un mes.

4. El camarero sirvió la comida mientras observaba el resultado del partido.

5. La pastelera horneaba los bollos que estaban rellenos de chocolate.

6. El hombre se convirtió en director del colegio donde estudió de joven.

7. El niño asustó a la paloma que picaba las sobras de pan de la merienda. 
8. Las cebras empezaron a correr cuando oyeron que alguien se aproximaba.

9. Los invitados aplaudieron a los novios mientras salían de la iglesia.

10. Los turistas visitaran las ruinas donde vivieron los primeros indígenas mayas.

11. Los padres observaban orgullosos mientras su hija recogía el diploma.

12. El fontanero respondió el teléfono mientras arreglaba la tubería.

13. El conductor de taxi regresó a la parada central de donde salió por la mañana.

14. La gacela atrapó a la liebre que corría libremente en el campo.

15. El tren de largo recorrido salió cuando sonó el pitido en la estación.

16. El microondas se estropeó cuando estaba a punto de calentarme la comida.

17. El reloj marcaba las tres en punto cuando salimos hacia la fiesta.

18. El filósofo leía un libro de antropología mientras escuchaba música clásica.

19. La limpiadora buscaba las llaves cuando las encontró en su bolsillo.

20. Los jóvenes mirabas las fotografías que sacaron en su último viaje de verano.

21. Los gemelos observaban a su madre mientras les preparaba la comida.

22. El actor compró las entradas para el musical que quería ver en Broadway.

23. El coordinador del departamento me dijo donde podía hacer fotocopias.

24. La presentadora anuncio el tiempo que iba a hacer el fin de semana.

\subsection{Distracters in Basque}

1. Doktorea erizaina begiratzen ari zen telefonoz hitz egiten zuen bitartean.

2. Klasean, irakasleak galdetzen zionean, ikasleak erantzuten zion.

3. Jokalariak, aurreko hilean garaituak izan ziren estadiora itzuli ziren.

4. Zerbitzariak janaria zerbitzatu zuen partiduko emaitza ikusten ari zen bitartean.

5. Pastelgileak txokolatez beteriko opeilak labekatzen zituen.

6. Gizona gaztetan ikasi zuen ikastetxeko zuzendaria bihurtu zen.

7. Umeak, askariko ogi-birrinen mokaduak jaten ari zen, usoa ikaratu zuen.

8. Zebrek, norbait gerturatzen ari zela entzun zutenean, korrika hasi zen.

9. Gonbidatuek, ezkonberriak txalotu zituzten elizatik irteten zebiltzatela.

10. Turistek, lehenengo indigena maiak bizi izan ziren hondakinak bisitatuko dituzte.

11. Gurasoek, bere alaba diploma hartzen ari zen bitartean, harro behatzen zuten.

12. Iturginek telefonoa hartu zuen hoditeria konpontzen zuela.

13. Taxi-gidaria goizean irten zen erdiko geralekura bueltatu zen.

14. Gazelak erbia harrapatu zuen, zeina landatik aske korrika zihoan.

15. Ibilbide luzeko trena, geltokian txistua jo zuenean, irten zen.

16. Mikrouhin-labea, janaria berotzear zegoenean, hondatu zen.

17. Erlojuak hirurak puntuan adierazten zuen, festarantz abiatu ginenean.

18. Filosofoa, musika klasikoa entzuten zebiltzala, antropologia-liburua irakurtzen zuen.

19. Garbitzailea giltzak bilatzen ari zen bere poltsikoan aurkitu zituenean.

20. Gazteak azkenengo udan ateratako argazkiak begiratzen ari ziren.

21. Bikiak bere ama begiratzen ari ziren, janaria prestatzen zien bitartean. 
22. Aktoreak Broadeway-n ikusi nahi zuen musikaleko sarrerak erosi zituen.

23. Sail-koordinatzaileak, fotokopiak non egin zitzakedan esan zidan.

24. Aurkezleak astebururako eguraldia iragarri zuen.

\subsection{Fillers in Spanish}

1. El perro del vecino mordió a mi prima de Valencia.

2. La abuela de Pedro se cayó por las escaleras de casa.

3. El hijo del panadero se levanta a las seis de la mañana.

4. La profesora de mi hijo habla catalán en clase.

5. El gato de Lucia araña a cualquier persona que ve.

6. La veterinaria de mi pueblo operó al perro de José.

7. El cantante del grupo se puso enfermo después del concierto.

8. La peluquera de Antonia le cortó la oreja el año pasado.

9. El director de la escuela preparara una reunión para los profesores.

10. El policía de tráfico vio como un coche se saltó el semáforo en rojo.

11. La amiga de Sofía engañó a su marido con otro hombre.

12. La profesión de Pablo no les gusta a sus padres.

13. El buzón de casa está lleno de cartas todavía por abrir

14. La cocinera de la cafetería incendio el comedor de la escuela.

15. El libro de matemáticas no explica bien como hacer los ejercicios.

16. La joven se convirtió en la gimnasta más joven en conseguir un título en el equipo.

17. Las fuertes tormentas dejaron sin luz a la población durante la noche.

18. El carpintero arregló el mueble del salón de mis padres en sólo tres horas.

19. Los niños se disfrazaron de payaso para las fiestas de carnaval del pueblo.

20. Los religiosos prepararon la misa para la Semana Santa de Sevilla.

21. El surfista conoció a su novia en las playas del norte de España.

22. El guitarrista de la banda hizo un solo durante el concierto de anoche.

23. El estudiante de química hizo un experimento en la clase de esta mañana.

24. La camiseta del jugador se rompió durante el último partido de la temporada.

\subsection{Fillers in Basque}

1. Nire auzokoaren txakurrak haginka egin zion nire Valentziako lehengusinari.

2. Pedroren amona etxeko eskaileretatik behera jausi zen.

3. Okinaren semea goizeko seietan altxatzen da.

4. Nire semearen irakasleak katalanez hitz egiten du klasean.

5. Luciaren katuak edonori egiten dio atzamarka.

6. Nire herriko albaitariak Joséren txakurra operatu zuen.

7. Taldeko abeslaria gaixotu egin zen kontzertuaren ostean.

8. Antoniaren ileapaintzaileak belarria ebaki zion iaz.

9. Eskolako zuzendaria batzar bat prestatzen ari da irakasleentzat.

10. Udaltzaingoak kotxe bat ikusi zuen semaforoa gorriz pasatzen.

11. Sofiaren lagunak bere senarrari iruzur egin zion beste gizon batekin. 
12. Pabloren lanbidea bere gurasoek ez dute gustoko.

13. Etxeko buzoia irakurri gabeko eskutizez betea dago.

14. Kafetegiko sukaldariak eskolako jantokiari su eman zion.

15. Matematikako liburuak ez du ariketak nola egin ondo azaltzen.

16. Gaztea taldeko gazteena bilakatu zen ititulu bat irabazten.

17. Ekaitza gogorrek populazioa argirik gabe utzi zuten gauean zehar.

18. Zurginak nire gurasoen egongelako altzaria hiru ordutan bakarrik konpondu zuen.

19. Umeak pailasoz mozorrotu ziren herriko ihauterietako jaietarako.

20. Erlijiosoek Sevillako Aste Santurako mesa prestatu zuten.

21. Surflariak Espainako iparraldeko hondartzetan ezagutu zuen bere neskalaguna.

22. Taldeko gitarristak bakar bat egin zuen berteko kontzertuan.

23. Kimikako ikaslek esperimentu bat egin du gaur goizeko klasean.

24. Jokalariaren kamiseta denboraldiko azkenengo partiduan apurtu zen.

\subsection{Conceptual sentences in Basque (low-attachment)}

1. Abeslariak/gona zeraman/mireslearen anaia/ agurtu zuen kontzertuan.

2. Dendaria/ krabata zermaman/ nagusiaren ilobaz/ arduratu zen atzo arratsean.

3. Irakasleak/ ezpainak gorriz margotuta zituen/ ikaslearen aitarekin/ hitz egin zuen.

4. Poliziak/ bikiak izan zituen opsitalean/ neskaren anaia/ galdekatu zuen.

5. Medikuak/ bizar zuri oso luzea zuen/ gizonaren alaba/ lagundu zuen.

6. Erreportalariak/ bular ebakuntza jasandako/ kirolariaren mutilari/ argazki bat egin zion orain dela gutxi.

7. Umeek/ hogei urterekin moja egin zen/ bizilagunaren semea/ begiratzen zuten.

8. Pilotuak/ hankak depilatzen zituen/ azafataren laguna/ begiratu zuen.

9. Soldaduak/ sei hilabetez haurdun zegoen/ komandantearen laguntzaileari/ idatzi zion.

10. Amak/ ilean txori urdina zeraman/ neskaren laguna/ deitu zuen.

11. Emakumeak/ lanerako traje grisa zeraman/ langilearen nagusia/ kontaktatu zuen.

12. Dendaria/ soineko zeraman/ nagusiaren ilobaz/ arduratu zen.

\subsection{Conceptual sentences in Basque (high-attachment)}

1. Abeslariak/ pajarita zeraman/mireslearen anaia/ agurtu zuen kontzertuan.

2. Dendaria/gona zeraman/ nagusiaren ilobaz/ arduratu zen atzo arratsean.

3. Irakasleak/ bigote ia zuria zeukan/ irakaslearen aitarekin/ hitz egin zuen.

4. Poliziak/ astebete prostata arazoekin zeramana/ neskaren anaia/ galdekatu zuen.

5. Medikuak/ ezpainak gorriz margoturik zituena/ gizonaren alaba/ lagundu zuen.

6. Erreportalariak/ bular ebakuntza jasandako orain dela gutxi/ kirolariaren mutilari/ argazki bat egin zion. 
7. Umeek/ hogei urterekin apaiz egin zen/ bizilagunaren semea/ begiratzen zuten.

8. Pilotuak/ egunero afeitatzen zena/ egunero/ begiratu zuen.

9. Soldaduak/ begiak marroiez margotzen zituen/ komandantearen laguntzaileari/ idatzi zion.

10. Amak/ krabata gorri-urdina zeraman/ neskaren laguna/ deitu zuen.

11. Emakumeak/ bart arratsean soinekoa zeraman/ langilearen nagusia/ kontaktatu zuen.

12. Dendaria/ lanerako traje grisa zeraman/ nagusiaren ilobaz/ arduratu zen.

\subsection{Conceptual sentences in Spanish (low attachment)}

1. El hombre gritó a la hermana del amigo que estaba sentado en el banco.

2. El doctor curó al vecino de la señora que era viuda desde hace un año.

3. Juan habló con el amigo de la periodista que estaba tumbada en la playa.

4. Las vecinas hablaron de la hija del actor que estaba casado desde hace un año.

5. El concursante abrazó a la amiga del conocido que estaba sentado entre el público.

6. Los estudiantes reclamaron a la ayudante del director que estaba enfadado en su despacho.

7. El policía arrestó al hermano de la cocinera que estaba enferma desde hace tiempo.

8. El cocinero seńaló al camarero de la mujer que estaba sentada en la mesa redonda.

9. El alcalde llamó a la secretaria del ejecutivo que estaba muy cansado de trabajar mucho.

10. Un perro mordió al sobrino de la emperatriz que estaba deprimida por su separación.

11. El periodista fotografió a la prometida del príncipe que fue consejero en $\mathrm{Ar}$ gentina en los 90.

12. María vio al sobrino de la mujer que estaba contenta por la noticia.

\subsection{Conceptual sentences in Spanish (high attachment)}

1. El hombre gritó al hermano de la amiga que estaba sentado en el banco.

2. El doctor curó a la vecina del señor que era viuda desde hace un año.

3. Juan habló con la amiga del periodista que estaba tumbada en la playa.

4. Las vecinas hablaron del hijo de la actriz que estaba casado desde hace un año.

5. El concursante abrazó al amigo de la conocida que estaba sentado entre el público.

6. Los estudiantes reclamaron al ayudante de la directora que estaba enfadado en su despacho.

7. El policía arrestó a la hermana del cocinero que estaba enferma desde hace tiempo. 
8. El cocinero señaló a la camarera del hombre que estaba sentada en la mesa redonda.

9. El alcalde llamó al secretario de la ejecutiva que estaba muy cansado de trabajar mucho.

10. Un perro mordió a la sobrina del emperador que estaba deprimida por su separación.

11. El periodista fotografió al prometido de la princesa que fue consejero en Argentina en los 90 .

12. María vio a la sobrina del hombre que estaba contenta por la noticia.

Michael Leeser

Department of Modern Languages and Linguistics

Florida State University

625 University Way

PO Box 3061540

Tallahassee, Florida 32306-1540

USA

Raquel Prieta

Department of Modern Languages and Literatures

O'Dowd Hall, Room 372

586 Pioneer Drive

Rochester, Michigan 48309-4482

USA 